\title{
Winter distribution of woodland caribou in relation to clear-cut logging in west-central Alberta
}

\author{
Kirby G. Smith, E. Janet Ficht, David Hobson, Troy C. Sorensen, \\ and David Hervieux
}

\begin{abstract}
The responses of a herd of migratory woodland caribou (Rangifer tarandus caribou) to timber harvesting that fragmented about $11 \%$ of their winter range in west-central Alberta were examined in this study. From 1981 to 1996, 45 caribou were radio-collared and monitored during the initiation and completion of first-pass timber harvest (50\% removal). Variables examined were home-range size, daily movement rates, and distance to the nearest cut block for radio-collared individuals. Daily movement rates and individual winter range sizes decreased as timber harvesting progressed. Caribou avoided using recently fragmented areas by an average of $1.2 \mathrm{~km}$. If fragmentation of the winter range continues through timber harvesting and other industrial activities, the "spacing out" antipredator strategy used by caribou may be compromised. Based on these findings, timber-harvesting strategies are recommended that (i) ensure an adequate area of usable habitat to support the current population, (ii) minimize the amount of fragmented area, and (iii) in the short term avoid presently defined core use areas.
\end{abstract}

\begin{abstract}
Résumé : Nous avons étudié les réactions d'un troupeau de Caribous des bois (Rangifer tarandus caribou) en migration à la coupe de bois qui a fragmenté environ $11 \%$ de son ravage dans le centre ouest de l'Alberta. De 1981 à 1996, 45 caribous ont été munis de colliers émetteurs et suivis depuis le début de l'opération de coupe de bois jusqu'à la fin de la première coupe (coupe de $50 \%$ ). Nous avons examiné la taille du domaine, les taux de déplacement et la distance jusqu'au parterre de coupe le plus proche. A mesure que la coupe progressait, les taux de déplacement quotidiens diminuaient et les caribous réduisaient les dimensions de leurs domaines d'hiver. Les caribous évitaient d'utiliser les zones fraîchement déboisées et s'en éloignaient de 1,2 km en moyenne. Si la fragmentation des ravages continue, coupe du bois, autres activités industrielles, la stratégie d'espacement utilisée par les caribous contre les prédateurs risque d'être compromise. D'après nos résultats, les stratégies recommandées lors de la coupe du bois sont les suivantes : $(i)$ ménager suffisamment de surface d'habitat utilisable pour supporter la population actuelle, (ii) minimiser la fragmentation, (iii) à court terme, éviter les zones actuelles d'utilisation maximale.
\end{abstract}

[Traduit par la Rédaction]

\section{Introduction}

Declines of woodland caribou populations following timber harvest within their range have been suggested on the basis of limited data (Bergerud 1974; Hristienko 1985; Edmonds 1991; Cumming 1992; Rettie and Messier 1998). Across Canada, wildlife and forest managers face conflicts in their attempts to integrate caribou habitat needs with timber harvest (Racey et al. 1991; Stevenson et al. 1991; Cumming 1992; Hervieux et al. 1996). Although a few studies have documented shortterm changes in movements and distribution in response to timber harvesting (Chubbs et al. 1993), simulated oil and gas exploration (Bradshaw et al. 1997), and haul-road activity (Cumming 1998), the long-term effects on caribou distribu-

Received October 26, 1999. Accepted May 17, 2000.

K.G. Smith, ${ }^{1}$ E.J. Ficht, D. Hobson, and T.C. Sorensen. Alberta Natural Resources Service, Suite 203,

111 - 54 Street, Edson, AB T7E 1T2, Canada.

D. Hervieux. Alberta Natural Resources Service,

1701 Provincial Building, 10320 - 99 Street, Grande Prairie, AB T8V 6J4, Canada.

${ }^{1}$ Author to whom all correspondence should be addressed (e-mail: Kirby.Smith@gov.ab.ca). tion and, more importantly, on population response to habitat loss and disturbance are not well documented.

Timber-harvesting plans for caribou range must consider this species' need for space to avoid predators (including humans) as well as the maintenance of its prime food source, lichens. Studies have shown that caribou distribute themselves spatially and temporally, presumably to reduce the risk of predation (Bergerud and Elliot 1986; Bergerud and Page 1987; Seip 1990, 1991; Edmonds and Smith 1991; Rettie and Messier 1998). In Ontario, timber-harvest guidelines have been designed for long-term maintenance of caribou populations, to the detriment of moose and deer populations (Racey et al. 1991); however, it is not clear yet what logging strategies will meet the spatial and foraging needs of caribou. Strategies proposed by various jurisdictions include large blocks of cut and reserve, smaller cut and leave blocks in 3 or more passes, or partial cut. In west-central Alberta, timberharvest plans for caribou range are being negotiated but are experimental in nature and must be monitored (Hervieux et al. 1996).

This paper presents some of the results from a long-term study of a migratory herd of woodland caribou that is estimated to number about 350 (Alberta Natural Resources Service, unpublished data). This herd winters in forested foothills and migrates to mountainous regions for calving, remaining 
Table 1. Sample sizes for radio-relocation data for the three study periods.

\begin{tabular}{lccc}
\hline & $1981-1984$ & $1987-1992$ & $1993-1996$ \\
\hline No. of radio-collared caribou ${ }^{a}$ & $11(6 \mathrm{M}: 5 \mathrm{~F})$ & $9(0 \mathrm{M}: 9 \mathrm{~F})$ & $25(1 \mathrm{M}: 24 \mathrm{~F})$ \\
No. of relocations & 110 & 121 & 701 \\
Mean no. of relocations per winter & 11.1 & 14.6 & 29.0 \\
Mean no. of days between locations & $11.7(1-47)$ & $25.8(5-99)$ & $10.7(3-62)$ \\
\hline \multicolumn{2}{c}{${ }^{a}$ The sex ratio is given in parentheses. } & &
\end{tabular}

in the mountains until snow accumulation triggers its return migration (Edmonds 1988). Specifically, we present an analysis of 16 years of winter range distribution data during timber harvest from 1981 to 1996 . The objective was to test for temporary or permanent exclusion of woodland caribou from harvested areas. We have used these results to recommend timber-harvesting strategies for caribou winter range in westcentral Alberta.

\section{Study area}

The $2468-\mathrm{km}^{2}$ study area was determined by a $95 \%$ confidence ellipse of all caribou telemetry locations between December 1 and April 30 from 1981 to 1996 . The study area was located in the foothills of west-central Alberta $\left(54^{\circ} \mathrm{N}, 119^{\circ} \mathrm{W}\right)$, approximately $40 \mathrm{~km}$ north of the town of Grande Cache. Limited access was provided by all-weather and dry-weather resource roads, cut lines, and pipelines. Most of the study area was within the Forest Management Agreement Area of Weyerhaeuser Canada Ltd. By the end of the study, $88 \mathrm{~km}^{2}$ of forest ( $4 \%$ of the winter range) had been harvested (Fig. 1); however, $274 \mathrm{~km}^{2}$ (11\% of the winter range) was affected by the resulting checkerboard pattern of cut and leave blocks. The study area includes 2 natural subregions, the Subalpine and the Upper Foothills (Beckingham et al. 1996). Elevation ranges from 1300 to $1800 \mathrm{~m}$. The climate is subarctic, characterized by short, cool, wet summers and long, cold, dry winters. The area is well forested. Dry sites support primarily pure lodgepole pine (Pinus contorta) or lodgepole pine - black spruce (Picea mariana) forests. There are scattered tamarack (Larix laricina) and black spruce muskegs, and at higher elevations on moist soil types there is a mixed balsam fir (Abies lasiocarpa), spruce (Picea spp.), and lodgepole pine forest. Willow (Salix spp.), shrub birch (Betula spp.), and some aspen (Populus tremuloides) interspersed with dry, grassy benches are found along the drainages.

Moose (Alces alces) and elk (Cervus elaphus) are the most abundant cervids, but mule deer (Odocoileus hemionus) and white-tailed deer (Odocoileus virginianus), as well as bighorn sheep (Ovis canadensis) and mountain goats (Oreamnos americanus), are present. Coyotes (Canis latrans), wolves (Canis lupus), grizzly bears (Ursus arctos), black bears (Ursus americanus), and cougars (Felis concolor) all occur within the study area. Further descriptions of the study area and this caribou herd are given in Bjorge (1984) and Edmonds (1988).

\section{Methods}

Woodland caribou were captured from a Bell 206 Jet Ranger helicopter with a net gun $(5 \times 5 \mathrm{~m}$ mesh discharged from a gun $)$ or hazed into tangle nets (Des Meules et al. 1971) between March 1981 and October 1994. Each animal was fitted with a VHF radio collar and ear tags.

Radio-collared caribou were captured and sampled during three study periods: (1) 1981-1984: initial stages of timber harvest, when new cut blocks made up $1.5 \%$ of the study area (5.5\% fragmented);
(2) 1987-1992: timber-harvesting activity, including a significant "step-out" into the middle of the winter range that increased fragmentation (2.9\% cumulative harvest, $10.0 \%$ fragmented); (3) 19931996: timber harvesting primarily in previously harvested areas (second pass), although an additional step-out area was harvested on the southern edge of the range, resulting in a small increase in fragmentation (3.6\% cumulative harvest, $11.0 \%$ fragmented). During the first two study periods, caribou were located by means of fixed-wing aircraft and helicopters, and locations were plotted on 1 : 250000 topographical maps. During the last study period, they were located by means of a helicopter equipped with a Global Positioning System (GPS). The accuracy of locations of radiocollared caribou varied from 100 to $400 \mathrm{~m}$ through the three study periods. The number of radio-collared animals, the number of relocations per animal, and the time interval between relocations varied throughout the study period (Table 1). Radio-collared caribou were monitored on the winter range from December 1 to April 30.

Home-range size for the herd during each study period was calculated using the program Home Range (Ackerman et al. 1990) to examine the influence of harvest activity on the distribution of the herd. Harmonic-mean home ranges were calculated to include $75 \%$ of the herd's utilization distribution. All caribou locations, including those slightly outside the study area, were used to calculated the herd's home range. An equal number of locations (121) from the last two study periods were randomly selected for calculating home ranges, so that all three study periods had the same sample size.

Avoidance of harvested areas by individual caribou was examined by comparing caribou locations and random locations within the study area. ANOVAs were used to compare the distances from caribou and random locations to the nearest cut block (SPSS Inc. 1998). Individual caribou and years were included as factors in the model and the model was run for both new cut blocks and all cut blocks. Additional ANOVAs were used to test for differences in distance to cut blocks between the sexes. All distance and area measurements were calculated with the ArcView GIS ${ }^{\circledR}$ program (Environmental Systems Research Institute 1996). Caribou locations were only included in the analysis if they were within the study area. Timber-harvesting activity was estimated to start 1 year prior to a "skid" (completion) date, therefore cut blocks were used in the analysis if their skid date was no more than 1 year after the caribou location date. Cut blocks were considered new if they were skidded within 1 year of the caribou location date.

To examine the influence of harvest activity on an individual caribou's home range, range sizes for radio-collared caribou were calculated for each winter using the minimum convex polygon method (Mohr 1947). A home range was only calculated for those individuals with 8 or more locations per winter (see also Bradshaw 1995). A regression was used to test for a relationship between the sizes of individual home ranges and the cumulative area harvested within the study area (SPSS Inc. 1998).

The distance each caribou moved per day was calculated by comparing the location of the individual with its previous location and dividing the distance by the number of days between relocations (Edmonds 1988). Travel rates were only calculated for 
Fig. 1. Clear-cut timber harvesting activity within the study area by year (May 1 to April 30) and season (summer and winter), 19751996.

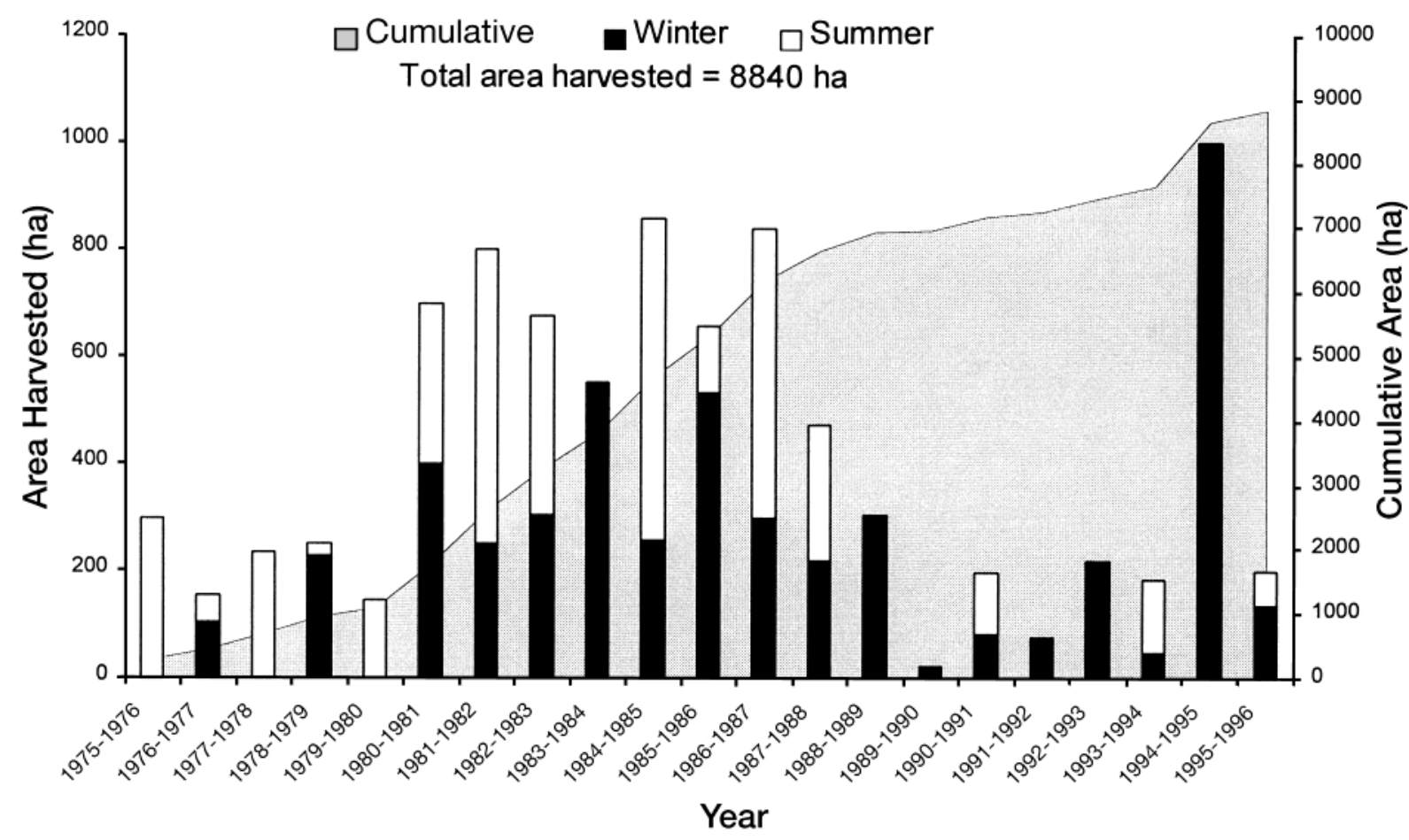

relocations that were less than 10 days apart. No travel rates were calculated for the second study period because of long time intervals between consecutive locations. Data from one of the winters in the first study period (1982-1983) were also excluded from the analysis because only 1 relocation was less than 10 days after the initial location. A regression was used to test for a relationship between distance travelled per day and cumulative area harvested within the study area (SPSS Inc. 1998). An ANOVA was used to test for differences in travel rates between the sexes.

\section{Results}

The total numbers of winter locations of individual caribou within the study area were 110,121 , and 701 for the three study periods. Table 1 presents radiotelemetry sample sizes for the three study periods. The sample of radio-collared animals consisted of adults only. The sex ratio of collared caribou varied among study periods (Table 1).

The herd's home-range sizes (75\% harmonic mean) remained similar among the three study periods: 951,985 , and $858 \mathrm{~km}^{2}$. However, the distribution of caribou relative to progressive timber harvest changed (Figs. 2-4). There was movement away from active cut blocks followed by a partial return to the original distribution after completion of firstpass logging (Figs. 2-4).

Caribou locations were, on average, $540 \mathrm{~m}$ farther from cut blocks than random locations within the study area, but this result was only marginally significant $\left(F_{[1,1749]}=3.6\right.$, $p=0.06)$. More significantly, caribou locations were $1.2 \mathrm{~km}$ farther from newly harvested cut blocks $(14.1 \pm 0.2 \mathrm{~km}$ $($ mean $\pm \mathrm{SE}))$ than were random locations $(12.9 \pm 0.2 \mathrm{~km})$ $\left(F_{[1,1749]}=16.5, p=0.0001\right)$. Significant variation in distance was additionally explained by individual caribou $\left(F_{[41,64]}=\right.$
2.0, $p=0.006)$ and years $\left(F_{[11,138]}=8.4, p=<0.0001\right)$. There were no significant differences in distance between the sexes (all cut blocks, $F_{[1,1850]}=0.5, p=0.48$; new cut blocks, $\left.F_{[1,1850]}=1.1, p=0.30\right)$.

Winter range sizes for individual caribou were negatively correlated with the cumulative amount of forest harvested within the study area $\left(F_{[1,3]}=29.4, R^{2}=0.91, p=0.01\right.$; Fig. 5). However, the trend must be interpreted cautiously because of small sample sizes in the first study period and unbalanced sampling of males and females (Fig. 5).

Daily movement rates were also negatively correlated with the cumulative amount of forest harvested within the study area $\left(F_{[1,6]}=7.2, R^{2}=0.54, p=0.04\right.$; Fig. 6). Daily movement rates were similar for males and females $\left(F_{[1,1042]}=\right.$ $3.2, p=0.07$ ).

\section{Discussion}

Determining a relevant study area is extremely important in this type of analysis. Several years of predisturbance distribution data might have indicated that caribou used much more of the area harvested. It was therefore conservative to define a study area as the $95 \%$ confidence ellipse of postdisturbance data. The difference between random locations and caribou locations would have been even greater if we had used a study area that overlapped more of the harvested area. For instance, caribou were, on average, $11.1 \pm 0.2 \mathrm{~km}$ from cut blocks. This could be considered the avoidance zone if harvested areas were previously the center of the home range.

Woodland caribou avoided areas that were being actively harvested. In the final stages of logging activity, only $0.6 \%$ 
Fig 2. Harmonic-mean home range (75\%) of caribou in the first study period (1981-1984) in relation to previous and active timber harvesting.

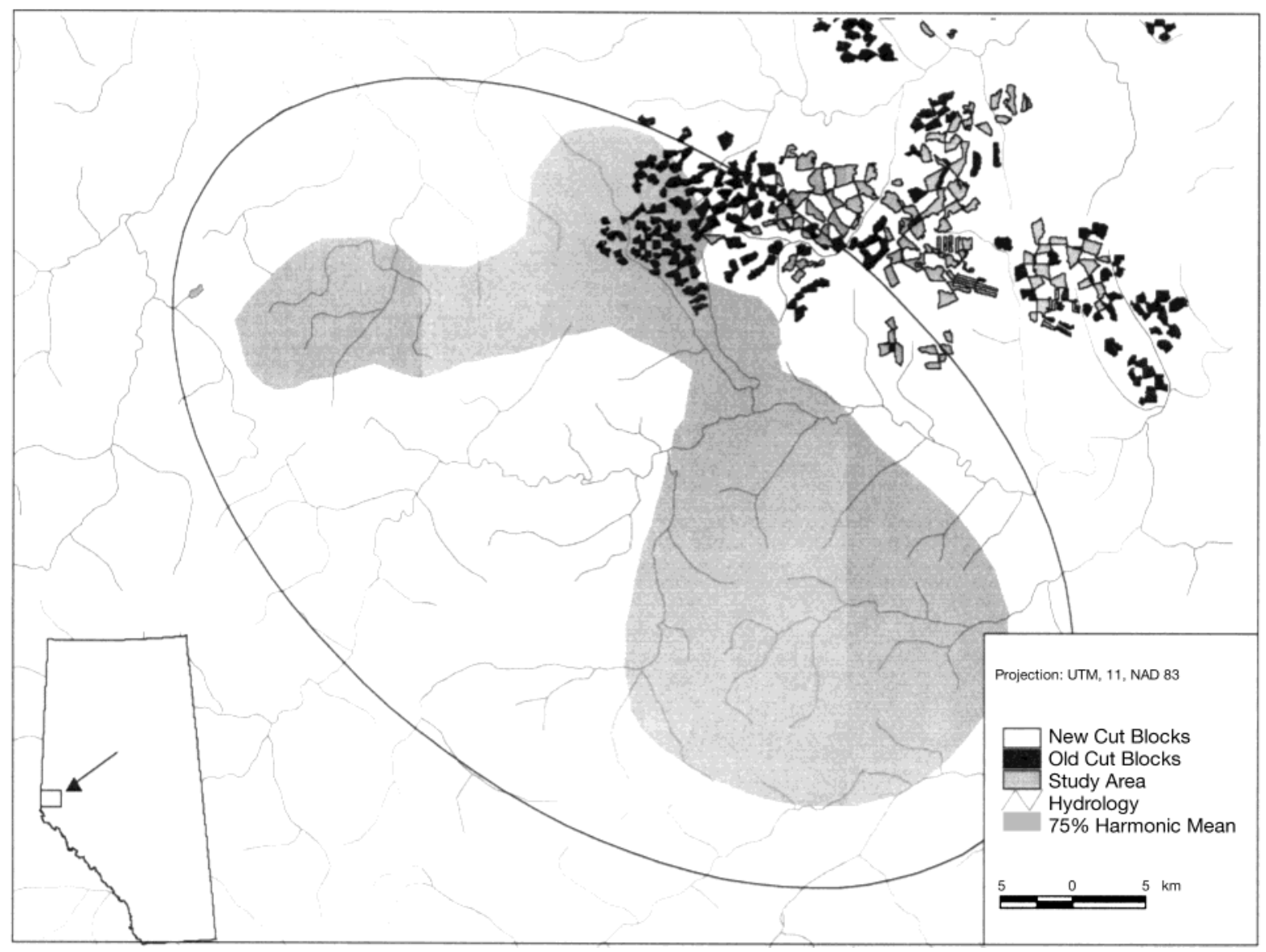

(4/701) of the radiolocations were found in clearcuts, which covered $3.6 \%$ of the study area. During the same time period, Stepaniuk (1997) back-tracked 59 woodland caribou trails (total length $69 \mathrm{~km}$, mean length $1.2 \mathrm{~km}$, range 0.05 $2.8 \mathrm{~km}$ ) during the winters of 1993-1995 and did not document a single instance of woodland caribou crossing a clearcut.

Stuart-Smith et al. (1997) suggested that caribou tend to avoid areas of diverse habitat types and boundaries between distinct habitat types, referred to as matrix habitat. Our study also confirms their avoidance of a specific type of matrix habitat. Standard two-pass logging results in a highly fragmented landscape following the first pass. Furthermore, second-pass blocks are typically harvested within 7-20 years of first-pass removal. If woodland caribou continue to avoid these logged areas for extended periods of time, availability of habitat at the landscape scale would be reduced. Alternatively, if caribou do not avoid this matrix habitat they could be exposed to higher predation rates as the alternative prey base increases in response to plant community succession (Racey et al. 1991; Rettie and Messier 1998).

There was no avoidance of fragmented areas during the initial stages of logging activity; however, during the following 12 years there was significant avoidance of harvested areas. We interpret this as a negative response by caribou to the progression of timber harvest into their winter range. Chubbs et al. (1993) provided evidence, obtained over a 4- year period, that caribou avoid clear-cutting or related disturbances during summer at distances up to $15 \mathrm{~km}$. Our study demonstrated similar avoidance over a longer term during winter.

Avoidance of industrial activity by the Central Arctic caribou herd in Alaska has also been documented. Dau and Cameron (1986) found that the density of maternal females was positively associated with the distance from roading. Nellemann and Cameron (1996) found that maternal females were displaced from preferred habitat types for up to $4 \mathrm{~km}$ from roading and oil-field facilities.

Daily movement rates were highest during the initial period of logging and decreased significantly with the accumulation of area harvested. Small sample sizes from the first study period may have led to overestimation of movement rates. During the latter stages of harvest, movement rates were within the range observed in northeastern Alberta during winter months $(0.64 \pm 0.13 \mathrm{~km} /$ day; Stuart-Smith et al. 1997); however, values for the initial stages of harvest were much higher.

Variables other than logging are known to influence movement rates and could have caused the variability of movement rates within study periods. Stuart-Smith et al. (1997) reported that movement rates of woodland caribou in northeastern Alberta decreased as snow depth increased at month end, and Bradshaw et al. (1997) suggested that this negative 
Fig. 3. Harmonic-mean home range (75\%) of caribou in the second study period (1987-1992) in relation to previous and active timber harvesting.

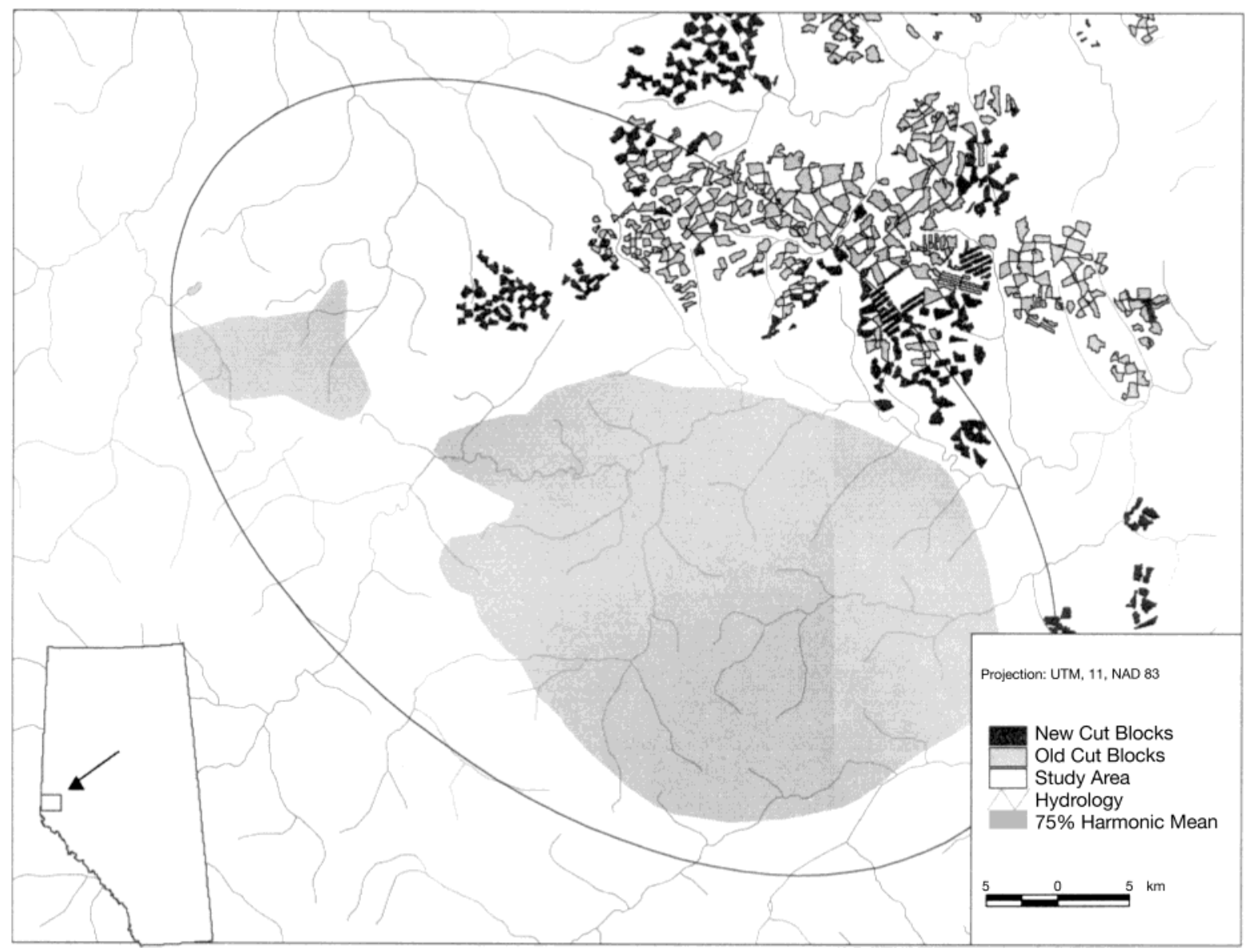

relationship was an energy-saving strategy. Our data did not identify a relationship between mean daily movement rates and November-April cumulative snow depths $\left(R^{2}=0.01\right)$. Wolf activity is another factor that could influence movement rates (Bergerud 1996); however, predator activity was not measured in our study.

Accurate inventories are extremely difficult to obtain on winter range, owing to dense forest overstory canopies. During the study period, the population was estimated to be ca. $350\left(0.14 / \mathrm{km}^{2}\right.$ in the study area). Based on calf survival to fall and annual mortality of the sample of radio-collared adults, the population appears to be stable or slightly declining (Alberta Natural Resources Service, unpublished data).

Existence at low densities is a key behaviour pattern of woodland caribou for maintaining a balance between recruitment and adult mortality (Seip 1991; Bergerud 1996). A land-use strategy that will not compromise this balance is recommended. A continuation of cut/leave harvesting on the winter range will increase the amounts of the preferred habitat (early seral stage forest) for moose, elk, and deer. This altered habitat would no longer be optimal for caribou, and the herd would concentrate at higher densities in the remaining range. This, in turn, could increase predation pressure (Racey et al. 1991; Seip 1991; Cumming 1992; Bergerud 1996) and result in a population reduction as predator-prey dynamics restore original densities in the remaining range (Bergerud 1992).

Over the 16 years of our study we documented avoidance in the spatial distribution of radio-collared caribou relative to active timber harvest, a decrease in mean winter range size for individual caribou, and a reduction in daily movement rates. Reduced individual home-range size and reduced movement rates may compromise the "spacing out" antipredator strategy (Seip 1991; Bergerud 1996) and result in higher mortality rates. Additionally, reduced movement rates may affect the ability of woodland caribou to seek suitable foraging sites within their winter range (Rettie and Messier 1998).

\section{Management implications}

Based on our results, we support the principles originally proposed by Hervieux et al. (1996) and the more general ecosystem system guidelines recommended by Seip (1998) regarding timber-harvest planning on woodland caribou range. Those specific to the current study include the following: (i) an area sufficient to support a viable population at densities characteristic of this species should be maintained; (ii) since caribou do not use areas of active timber harvest, fragmentation should be minimized by localizing the timber harvest in terms of both time and space; and (iii) in the short term, 
Fig. 4. Harmonic-mean home range (75\%) of caribou in the last study period (1993-1996) in relation to previous and active timber harvesting.

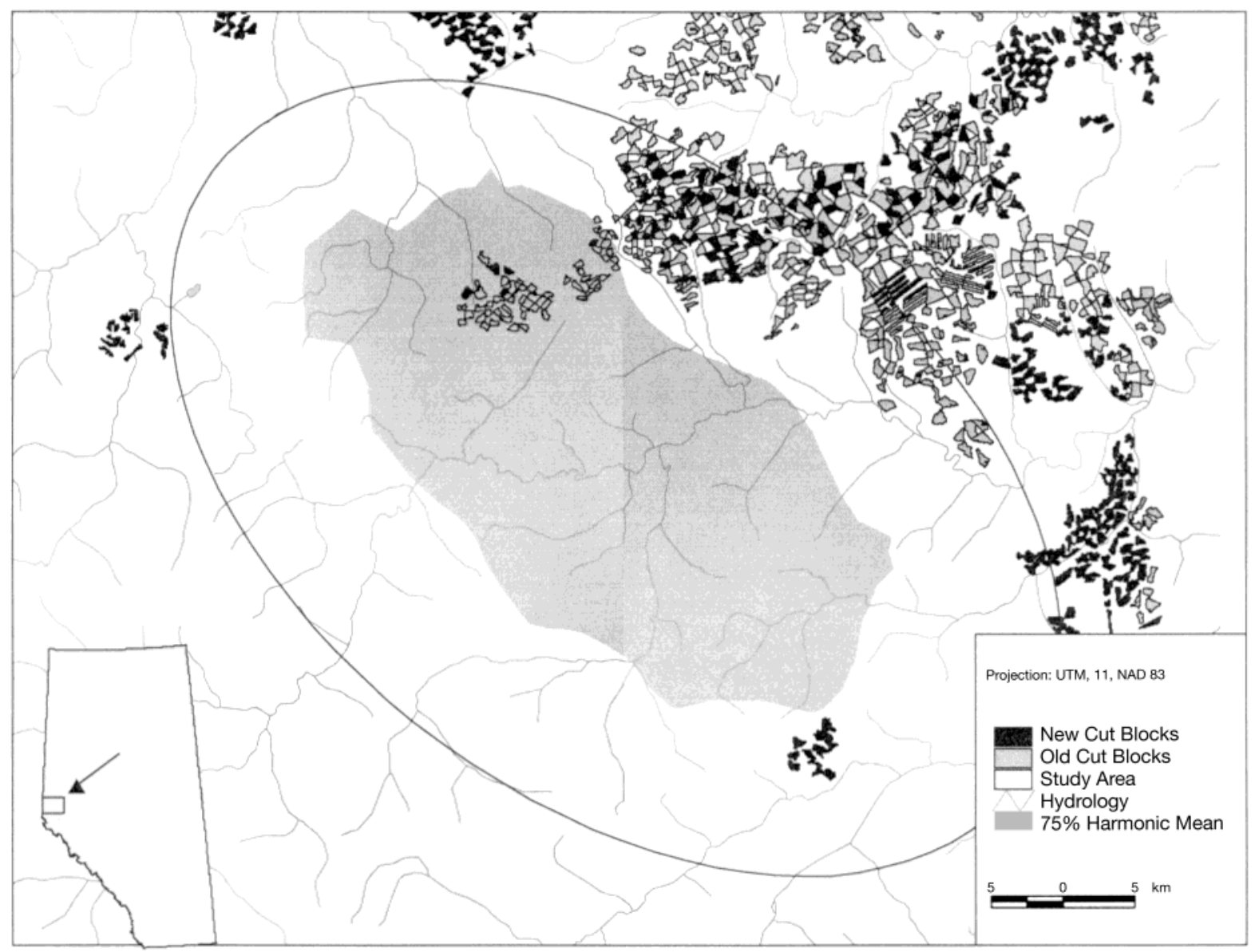

Fig. 5. Winter range sizes (mean \pm SE) for radio-collared caribou plotted against the accumulation of harvested area within the study area. The number of individuals and their sex are indicated beside each data point.

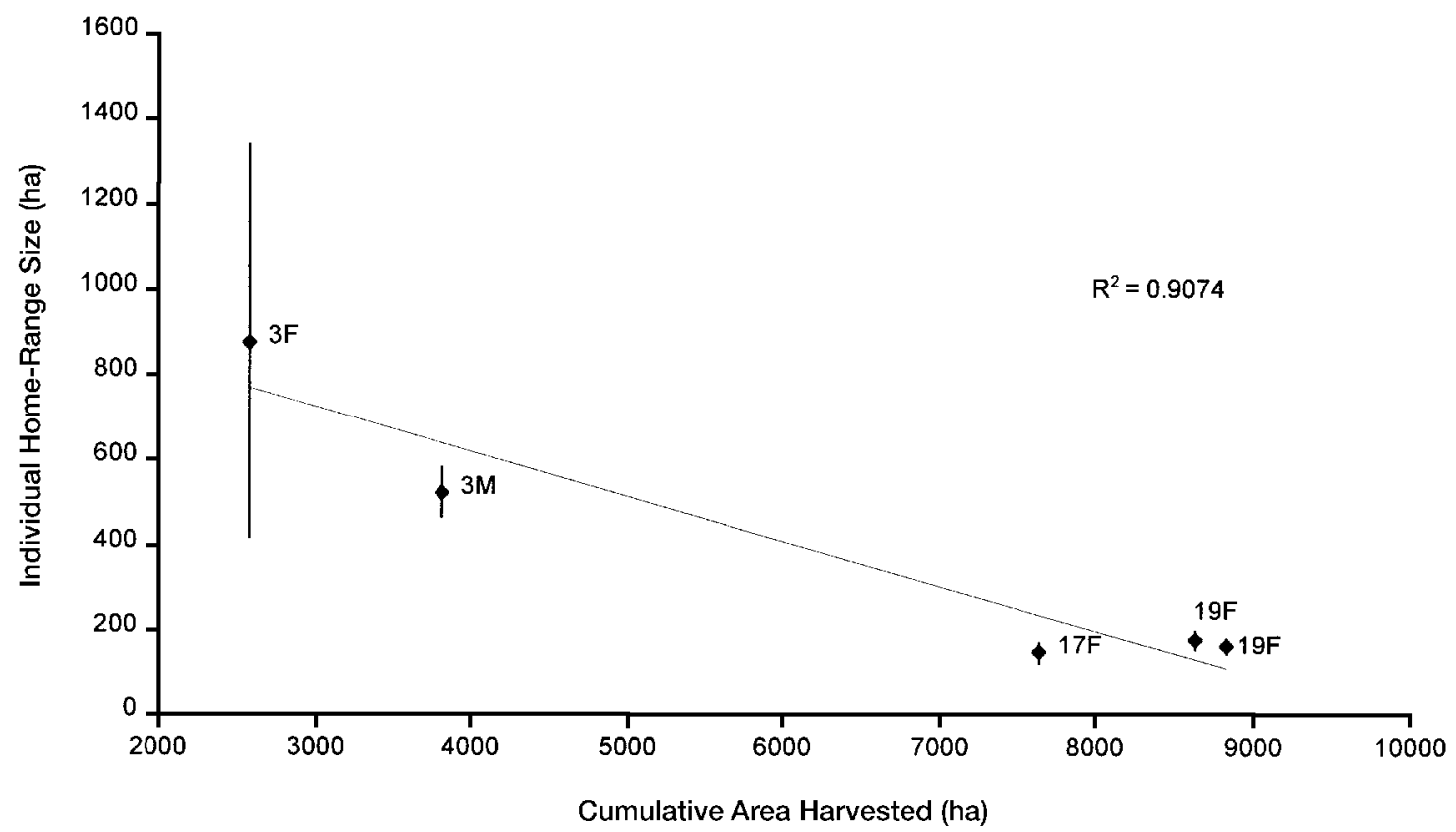

timber harvesting should avoid presently defined core areas, as recommended by Darby and Duquette (1986), Cumming (1992), and Cichowski and Banner (1993). If timber harvest is unavoidable, larger blocks are recommended in order to (i) minimize edge effect, which may increase habitat for alternative prey species (moose, elk, deer) and (ii) mimic 
Fig. 6. Daily travel (mean \pm SE) of radio-collared caribou plotted against the accumulation of harvested area within the study area. The data were limited to locations within the study area and to intervals of less than 10 days. The sample size for distance intervals is indicated beside each data point.

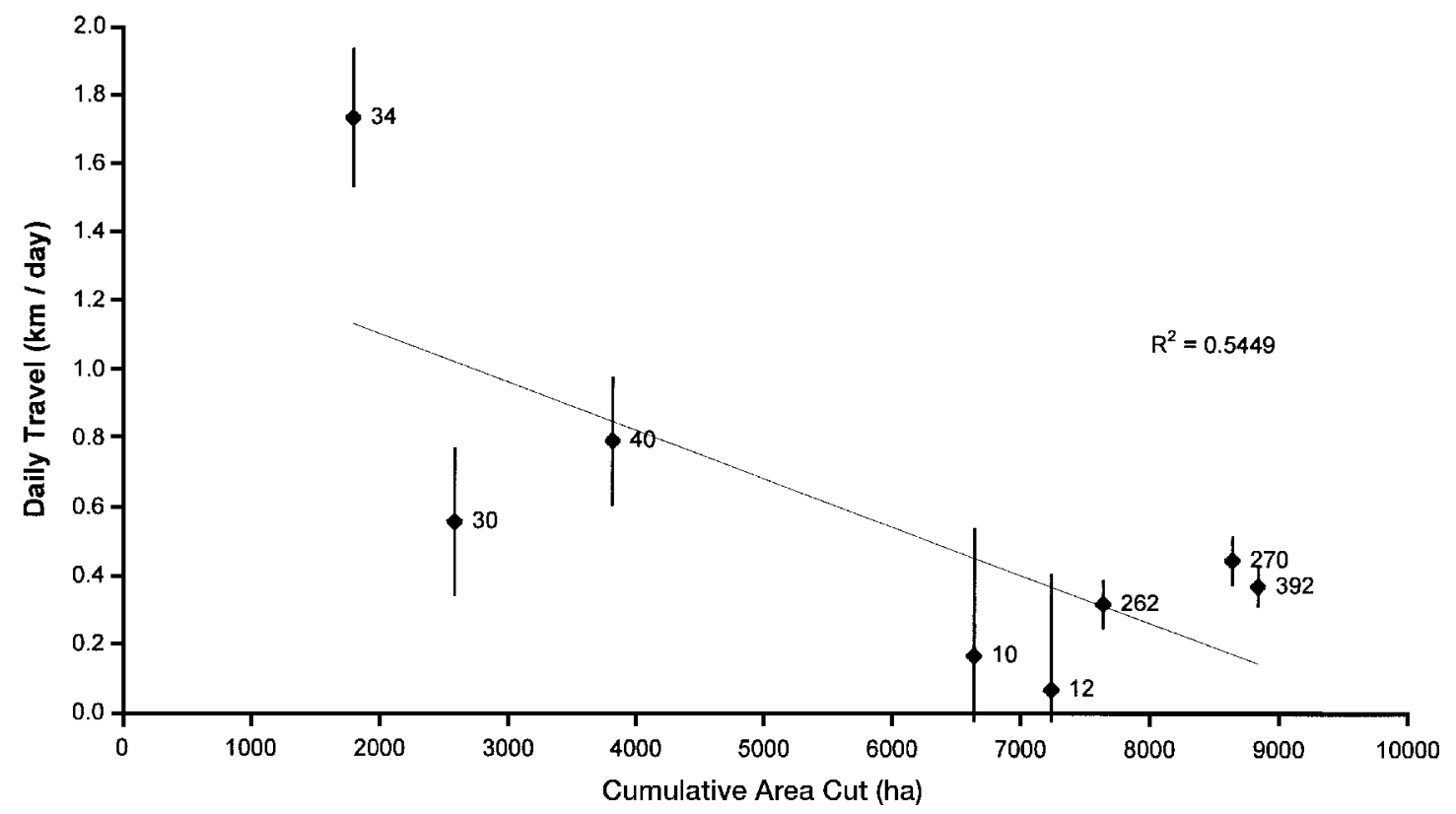

large-scale fire patterns (which are common in this region) to provide future caribou habitat (i.e., in $80+$ years).

New approaches to exploiting the timber resource on caribou range need investigating. Alternatives to clear-cutting (i.e., selection cut) should be examined for the purpose of maintaining habitat structure at the landscape scale. In addition, a cumulative-impact assessment of all human activities in this caribou range is required. Until such knowledge is gained, we recommend a conservative approach to other resource development (coal mining, oil and gas development, recreational activities). Given the lack of templates for successfully integrating timber harvest and other human activities with woodland caribou habitat, it is advisable to minimize habitat loss and fragmentation.

\section{Acknowledgements}

The final component of this study was made possible through the Foothills Model Forest Program sponsored by Forestry Canada's Green Plan. Staff of Alberta Natural Resources Service designed and carried out the project. Weyerhaeuser Canada met digital forest inventory needs and provided helicopter support. We thank R. Poole for his continued assistance in this regard. In addition, Nova Corporation and the Alberta Lands and Forest Service contributed financially to the project. Over the 16 years that data were collected, many people contributed their time and thoughts to the studies and we thank them all. Particular appreciation goes to the pilots and observers who flew hundreds of hours in search of radio-collared caribou in the foothills and mountains of west-central Alberta, and to B. Goski for his net-gunning skills. We thank H. Armbruster, M. Festa-Bianchet, A. James, P. Jones, J. Rettie, C. Rohner, D. Seip, G. Stenhouse, A. Todd, D. Thomas, and two anonymous referees for reviewing and improving drafts of this paper.

\section{References}

Ackerman, B.F., Samuel, M., and. Garton, E. 1990. User's manual for program Home Range. Tech. Rep. No. 15, Forest, Wildlife and Range Experiment Station, University of Idaho, Moscow.

Beckingham, J.D., Corns, I.G.W., and Archibald, J.H. 1996. Field guide to the ecosites of west-central Alberta. The University of British Columbia Press, Vancouver.

Bergerud, A.T. 1974. Decline of caribou in North America following settlement. J. Wildl. Manag. 38: 757-770.

Bergerud, A.T. 1992. Rareness as an antipredator strategy to reduce predation risk for moose and caribou. In Wildlife 2001: populations. Edited by D.R. McCullough and R.H. Barrett. Elsevier Applied Science, New York. pp. 1008-1021.

Bergerud, A.T. 1996. Evolving perspectives on caribou population dynamics: have we got it right yet? Rangifer Spec. Issue No. 9. pp. 95-115.

Bergerud, A.T., and Elliot, J.P. 1986. Dynamics of caribou and wolves in northern British Columbia. Can. J. Zool. 64: 15151529.

Bergerud, A.T., and Page, R.E. 1987. Displacement and dispersion of parturient caribou at calving as antipredator tactics. Can. J. Zool. 65: 1597-1606.

Bjorge, R.R. 1984. Winter habitat use by woodland caribou in west central Alberta with implications for management. In Fish and wildlife relationships in old-growth forests. Edited by W.R. Meehan, T.R. Merrell, Jr., and T.A. Hanley. American Institute of Fishery Research Biology, Juneau, Alaska. pp. 335-342.

Bradshaw, C.J.A., Hebert, D.M., Rippin, A.B., and Boutin, S. 1995. Winter peatland habitat selection by woodland caribou in northeastern Alberta. Can. J. Zool. 73: 1567-1574.

Bradshaw, C.J.A., Boutin S., and Hebert, D.M. 1997. Effects of petroleum exploration on woodland caribou in northeastern Alberta. J. Wildl. Manag. 61: 1127-1133.

Chubbs, T.E., Keith L.B., Mahoney, S.P., and McGrath, M.J. 1993. Responses of woodland caribou (Rangifer tarandus caribou) to clear-cutting in east-central Newfoundland. Can. J. Zool. 71: 487-493. 
Cichowski, D.B., and Banner, A. 1993. Management strategy and options for the Tweedsmuir-Etiako caribou winter range. Land Management Rep. No. 83, British Columbia Ministry of Forests, Victoria.

Cumming, H.G. 1992. Woodland caribou: facts for forest managers. For. Chron. 68: 481-492.

Cumming, H.G. 1998. Experimental log hauling through a traditional caribou winter range. Rangifer Spec. Issue No. 10. pp. 241-258.

Darby, W.R., and Duquette, L.S. 1986. Woodland caribou and forestry in Northern Ontario, Canada. Rangifer Spec. Issue No. 1. pp. 87-93.

Dau, J.R., and Cameron, R.D. 1986. Effects of a road system on caribou distribution during calving. Rangifer Spec. Issue No. 1. pp. 95-101.

Des Meules, P., Simard, B.R., and Brassard, J.M. 1971. A technique for the capture of caribou, Rangifer tarandus, in winter. Can. Field-Nat. 85: 221-229.

Edmonds, E.J. 1988. Population status, distribution, and movements of woodland caribou in west central Alberta. Can. J. Zool. 66: $817-826$.

Edmonds, E.J. 1991. Status of woodland caribou in western North America. Rangifer Spec. Issue No. 7. pp. 91-107.

Edmonds, E.J., and Smith, K.G. 1991. Mountain caribou calf production and survival, and calving and summer habitat use in west central Alberta. Wildlife Res. Ser. No. 4, Alberta Fish and Wildlife, Edmonton.

Environmental Systems Research Institute Inc. 1996. ArcView GIS. Environmental Systems Research Institute Inc., Redlands, Calif.

Hervieux, D., Edmonds, J., Bonar, R., and McCammon, J. 1996. Successful and unsuccessful attempts to resolve caribou management and timber harvesting issues in west central Alberta. Rangifer Spec. Issue No. 9. pp. 185-192.
Hristienko, H. 1985. The impact of logging on woodland caribou (Rangifer tarandus caribou): a literature review. Tech. Rep. No. 853, Manitoba Natural Resources and Wildlife, Winnipeg.

Mohr, G.O. 1947. Table of equivalent populations of North American small mammals. Am. Midl. Nat. 37: 223-249.

Nellemann, C., and Cameron, R.D. 1998. Cumulative impacts of an evolving oil-field complex on the distribution of calving caribou. Can. J. Zool. 76: 1425-1430.

Racey, G.D., Abraham, K., Darby, W.R., Timmermann, H.R., and Day, Q. 1991. Can woodland caribou and the forest industry coexist? Rangifer Spec. Issue No. 7. pp. 108-115.

Rettie, W.J., and Messier, F. 1998. Dynamics of woodland caribou populations at the southern limit of their range in Saskatchewan. Can. J. Zool. 76: 251-259.

Seip, D.R. 1990. Ecology of woodland caribou in Wells Gray Provincial Park. Wildlife Bull No. B-68, British Columbia Ministry of the Environment, Victoria.

Seip, D.R. 1991. Predation and caribou populations. Rangifer Spec. Issue No. 7. pp. 46-52.

Seip, D. 1998. Ecosystem management and the conservation of caribou habitat in British Columbia. Rangifer Spec. Issue No. 10.

SPSS Inc. 1998. SPSS ${ }^{\circledR}$ for Windows. SPSS Inc., Chicago, Ill.

Stepaniuk, D.W. 1997. Planning for woodland caribou habitat needs in west-central Alberta. M.Sc. thesis, University of Alberta, Edmonton.

Stevenson, S.K., Child, K.N., Watts, G.S., and Terry, E.L. 1991. The mountain caribou in managed forest program: integrating forestry and habitat management in British Columbia. Rangifer Spec. Issue No. 7. pp. 130-136.

Stuart-Smith, A.K., Bradshaw, C.J.A., Boutin, S., Hebert, D.M., and Rippin, A.B. 1997. Woodland caribou relative to landscape patterns in northeastern Alberta. J. Wildl. Manag. 61: 622-633. 